\title{
Article
}

\section{Recent finance advances in information technology for inclusive development: a systematic review}

\author{
Asongu, Simplice A and Nwachukwu, Jacinta Chikaodi \\ Available at http://clok.uclan.ac.uk/24661/ \\ Asongu, Simplice A and Nwachukwu, Jacinta Chikaodi ORCID: 0000-0003- \\ 2987-9242 (2018) Recent finance advances in information technology for \\ inclusive development: a systematic review. NETNOMICS: Economic Research \\ and Electronic Networking, 19 (1-2). pp. 65-93. ISSN 1385-9587
}

It is advisable to refer to the publisher's version if you intend to cite from the work. http://dx.doi.org/10.1007/s11066-018-9127-0

For more information about UCLan's research in this area go to http://www.uclan.ac.uk/researchgroups/ and search for <name of research Group>.

For information about Research generally at UCLan please go to http://www.uclan.ac.uk/research/

All outputs in CLoK are protected by Intellectual Property Rights law, including Copyright law. Copyright, IPR and Moral Rights for the works on this site are retained by the individual authors and/or other copyright owners. Terms and conditions for use of this material are defined in the policies page.

\section{CLoK}

Central Lancashire online Knowledge www.clok.uclan.ac.uk

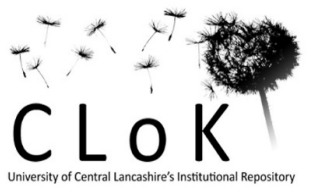




\title{
Recent finance advances in information technology for inclusive development: a systematic review
}

Forthcoming in NETNOMICS: Economic Research and Electronic Networking

(DOI: 10.1007/s11066-018-9127-0)

\author{
Simplice A. Asongu \\ Development Finance Centre, Graduate School of Business, \\ University of Cape Town Cape Town South Africa. \\ $\&$ \\ Department of Economics \& Development Studies, \\ Covenant University, Ota, Ogun State, Nigeria \\ E-mails: asongusimplice@yahoo.com / asongus@afridev.org \\ Jacinta C. Nwachukwu \\ Lancashire School of Business and Enterprise, \\ University of Central Lancashire \\ Preston PR1 2HE \\ United Kingdom \\ Email: j.ch.nwachukwu@gmail.com
}

\begin{abstract}
The overarching question tackled in this paper is: to what degree has financial development contributed to providing opportunities of human development for those on low-incomes and by what information technology mechanisms? We systematically review about 180 recently published papers to provide recent information technology advances in finance for inclusive development. Retained financial innovations are structured along three themes. They are: (i) the rural-urban divide, (ii) women empowerment and (iii) human capital in terms of skills and training. The financial instruments are articulated with case studies, innovations and investment strategies with particular emphasis, inter alia on: informal finance, microfinance, mobile banking, crowdfunding, microinsurance, Islamic finance, remittances, Payment for Environmental Services (PES) and the Diaspora Investment in Agriculture (DIA) initiative.
\end{abstract}

JEL Classification: G20; I10; I20; I30; O10

Keywords: Finance; Inclusive Growth; Economic Development 


\section{Introduction}

'Output may be growing, and yet the mass of the people may be becoming poorer' (Lewis, 1955). The celebrated 'Capital in the $21^{\text {st }}$ Century' (Piketty, 2014) has re-ignited the debate surrounding “immiserizing growth"1 (Bhagwati, 1958) and debunked Kuznets' $(1955,1971)$ conjecture on an inverted U-shape nexus between inequality and industrialisation. The paradigm shift is consistent with a strand of the literature which underlines the need to clearly articulate income-inequality in poverty-growth relationships (Kalwij \& Verschoor, 2007; Thorbecke, 2013; Fosu, 2015). These include, among others: the instrumentality of growth elasticities in policy making (Adam, 2004); the critical dimension of inequality in poverty alleviation (Datt \& Ravallion, 1992; Kakwani, 1993; Ali \& Thorbecke, 2000) and the importance of inequality in growth elasticities of poverty (Easterly, 2000; Fosu, 2015; Ravallion, 1997). Hence, Piketty's coverage of developed countries is broadly in line with the narratives in African countries (Fosu, 2008, 2009, 2010a, 2010b) and a broad sample of developing economies (Fosu, 2010c, Asongu, 2016).

While the debate on financial globalisation is still ongoing as opposed to that on trade liberalisation which has reached some moderate consensus ${ }^{2}$, two important trends have characterised the phenomenon of globalisation over the past three decades: growing inequality and increasing international financial liberalisation (Azzimonti et al., 2014). There is evidence of this in both advanced and developing countries. For the former countries (i) Piketty (2014) and Atkinson et al. (2011) have documented soaring inequality while (ii) Abiad et al. (2008) and Obstfeld \& Taylor (2005) have provided evidence of growing capital mobility. As for the developing economies (i) the imposed structural adjustment policies promoted financial openness (Batuo et al., 2010; Batuo \& Asongu, 2015) and (ii) there is a consensus on growth inequality, with the exceptions of South East Asian and Latin American countries that have

\footnotetext{
1 Economic growth could be followed by considerable negative externalities and eventually produce disequalizing distribution in the fruits of economic prosperity. Such a scenario runs counters to Kuznets' (1955, 1971) conjectures on an $n$-shape nexus between inequality and industrialisation.

${ }^{2}$ Whereas, the theoretical underpinnings of financial globalisation sustain the claim that this phenomenon is a means of efficient allocation of capital and international sharing of risks, there is a narrative in the literature not supporting the strand on more rewards in less-developed countries simply because they are rich in labour and scarce in capital (Kose et al., 2006; Henry, 2007; Kose et al., 2011). The counteracting strand attributes global financial instability to growing capital account openness (Stiglitz, 2000; Bhagwati, 1998; Rodrik, 1998; Motelle \& Biekpe, 2015). Its anti-thesis questions the benefits of financial liberalisation in terms of stability in developed countries and economic prosperity in less developed nations (Fischer, 1998; Summers, 2000). It further claims that the whole idea of financial globalisation has the obscure motivation of extending the benefits of international trade to those with assets (Asongu, 2014a).
} 
experienced low growth accompanied with lower inequality (Asongu, 2016) . $^{3}$ A notable trend of how increasing globalisation is related to finance and poverty is the liberalisation of the information and communication technology (ICT) sector. This has led to a (i) burgeoning pro-poor mobile phone penetration (Asongu, 2015a): (ii) pro-poor connection that is more significant in magnitude when mobile telephony is used for banking (Asongu \& Nwachukwu, 2016ab). Hence, there is an apparent policy challenge of structuring recent advances in financial development for inclusive growth.

To the best of our knowledge, recent literature on inclusive growth has focused on: gender equality (Elu \& Loubert, 2013; Anyanwu, 2013a; Baliamoune-Lutz, 2007; Anyanwu, 2014a; Baliamoune-Lutz \& McGillivray, 2009), eco-socialism (Singh, 2014), poverty correlates (Anyanwu, 2013b, 2014b), linkages between finance, growth, employment and poverty (Odhiambo, 2009, 2011), the role of financial development in poverty reduction (Odhiambo, 2010a, 2010b, 2013; Asongu \& Nwachukwu, 2017), linkages between human development, information technology and mobile banking in inclusive development (Asongu \& Nwachukwu, 2018; Asongu \& le Roux, 2017), debates between relative pro-poor (Dollar \& Kraay, 2003) and absolute pro-poor (Ravallion \& Chen, 2003) growth, determinants and measurements of inclusive growth (Mlachila et al., 2017; Anand et al., 2013) and inclusive finance. The present systematic review is an extension of the last strand.

Exclusive growth is fundamentally driven by irrational financial policies ( $\mathrm{Li}$ et al., 2011, p. 109) and inequality remains the principal challenge of 21 century capitalism (Brada $\&$ Bah, 2014). These have consolidated a growing strand of literature on inclusive financial development. In essence, the policy debate is fundamentally shifting away from the narrow focus of the finance-growth nexus to poverty mitigation. Instead, there is a growing concern in the development community about inequality and processes of distributing the rewards of the finance-growth interconnection.

Access to finance contributes substantially to enabling individuals to exploit new avenues. Such inclusive financial development has a great potential of creating opportunities for low-income and/or marginalised groups. Consequently, avenues that could be confined to certain social and economic classes are made more accessible to the underprivileged. While

\footnotetext{
${ }^{3}$ It should be noted that the comparison, which is for the last three decades, (1980-2010), may also contradict recent strands (1990-2010) on poverty reduction in Africa (Young, 2012) or the continent being on time for some Millennium Poverty Targets (Pinkivskiy \& Sala-i-Martin, 2014). Accordingly, trends are contingent on sample periodicity: 1995-2010 versus 1980-2010 (see Fosu, 2015).
} 
these issues have been substantially shown to be of prime importance in the United Nation's (UN's) post-2015 Sustainable Development Goals (SDGs) which are replacing the Millennium Development Goals (MDGs), to the best of our knowledge, we are unaware of a study that has systematically provided a review of recent advances in financial development for inclusive growth (United Nations: UN, 2013, pp. 7-13). This represents a substantial gap in the literature. Accordingly, the present exposition provides a research of financial development instruments for poverty alleviation, reduction of inequalities and novel opportunities for growth.

In the light of the extant literature and policy challenges, this study contributes to existing scholarship by providing a comprehensive study of the role of financial development in distributing the benefits of economic prosperity and information technology instruments by which some fundamental inequalities could be addressed or redressed ${ }^{4}$. Its key contribution to the literature is to document recent advances in ways 'information technology-driven' financial progress could promote inclusive development. Moreover, we also concurrently discuss policy choices in this regard that would benefit more equitable income distribution. In a nutshell, the overarching question tackled in this paper is: to what degree has financial development contributed to providing opportunities of human development for those in the low-income strata and by what information technology mechanisms has it done so?

In order to address the highlighted issues, the analytical procedure consists of first situating concerns of non-inclusive development within the context of contemporary literature before reviewing studies on the recent information technology advances in finance for inclusive development. Discussion on the information technology innovations are structured along three principal themes. They are (i) the rural-urban divide, (ii) women empowerment and (iii) human capital in terms of skills and training. The financial instruments are then supported with case studies and investment strategies with particular emphasis on informal finance, microfinance, mobile banking, crowdfunding, microinsurance, Islamic finance, remittances, PES and the DIA initiative.

Information technology has been established to improve: living standards (Chavula, 2013); growth (Qureshi, 2013a; Levendis \& Lee, 2013); welfare externalities (Carmody, 2013; Qureshi, 2013bc); life for all (Kivunike et al., 2011); sustainable growth (Byrne, 2011)

\footnotetext{
${ }^{4}$ Stakeholders constitute the civil society and both broad (e.g. Islamic banking) and narrow (e.g. mobile banking) perspectives of financial development are considered.
} 
and banking sector development (Kamel, 2005) in developing countries ${ }^{5}$. Whereas information technology has been documented to bring about social, economic and human development benefits, a research of how it has consolidated the role of finance in inclusive development is to the best of our knowledge still missing in the literature.

The concept of inclusive growth employed in this study embodies both relative propoor and absolute pro-poor versions of the phenomenon ${ }^{6}$. We resist engaging in the debate over which version of inclusive growth is better and focus on a broader concept of pro-poor growth in the perspectives of Swamy (2010, p.56) and Ifzal (2007, p. 55) which entail, inter alia: economic wellbeing and equal opportunities. In the same vein, the conception of finance in the paper is tailored towards a strategy of inclusive growth which, according to Swamy consists of prioritising the development of inclusive financial systems that are socially and financially sustainable.

We also devote some space to consolidating this line of inquiry with some interesting views and stylized facts. World Hunger (2010) has argued that, the main cause of hunger and poverty in the world today is the underlying economic system which encourages a minority to control a vast majority of global wealth while the bottom billion is just left to survive. Income inequality has risen sharply over the past decade (Milanovic, 2011). According to Joseph Stiglitz: "There has been no improvement in well-being for the typical American family for 20 years. On the other side, the top one percent of the population gets 40 percent more in one week than the bottom fifth receive in a full year". (Nabi, 2013, p.10). Some accounts sustain that the Top 1 percent have gained all the income from the recent economic recovery (Covert, $2015)^{7}$ or that the income of the Top 1 percent is projected to surpass that of the Bottom 99 percent by 2016 (Oxfam, 2015). Hence, there is an urgent "Need to design the right economic policies to enhance inclusiveness specially in the developing countries" (Nabi, 2013, p. 13) ${ }^{8}$. It includes, among others; the restoration of finance as a fundamental force for inclusive and sustainable development (Freeman, 2010).

\footnotetext{
${ }^{5}$ This is also a recent stream of literature on the relevance of ICT on inclusive development in developing countries (Afutu-Kotey et al., 2017; Asongu \& Boateng, 2018; Bongomin et al., 2018 ; Gosavi, 2018; Hubani \& Wiese, 2018; Isszhaku et al., 2018; Minkoua Nzie et al., 2018; Muthinja \& Chipeta, 2018; Abor et al., 2018).

${ }^{6}$ To put in simple terms, absolute pro-poor growth is growth that benefits the poor via poverty reduction, while relative pro-poor growth benefits the poor through income-inequality mitigation. The interested reader can find more on the debate in Mlachila et al. (2017).

${ }^{7}$ Nabi $(2013$, p. 12) on the Global Housing crisis estimates that 100 million are homeless, 1.6 billion have substandard housing conditions and an estimated 3 billion people are expected to be live in slums by 2050 .

${ }^{8} \mathrm{Nabi}$ (2013) is quoted both with respect to developed and developing countries. The three issues are selected because they represent some hard stylized facts on how financial development can substantially transform the nature of social and economic opportunities in societies.
} 
The structure of the systematic review is organised by building on a fundamental understanding of how social and economic progress increase people's capabilities/possibilities for enhancing their material and non-material wellbeing. Issues like the rural/urban divide, gender gap and human capital are discussed. There is also a clear articulation of how financial development can fundamentally transform the nature of social, political and economic opportunities in societies. Many examples are cited of how mobile money/banking improves conditions for entrepreneurship and how such conditions can: (i) lead to inclusive human development (if the entrepreneurship is engaged by the poor); (ii) reduce the rural-urban divide (if the entrepreneurship is in rural areas) and (iii) empower the female gender (if female entrepreneurs are concerned). This is consistent with recent conclusions in the literature that mobile phones stimulate entrepreneurship (Asongu et al., 2018) and entrepreneurship increases inclusive human development (Asongu \& Odhiambo, 2018).

The rest of the paper is organised as follows. The methodology is discussed in Section 2. Section 3 focuses on the urban-rural divide. New financial instruments for empowering women are discussed in Section 4, whereas human capital in terms of skills and training is reviewed in Section 5. New trends on financial informality, microfinance, crowdfunding, microinsurance and Islamic finance are covered in Section 6. Section 7 concludes.

\section{Methodology of the systematic review}

Papers used in the research are collected after an extensive search from February 2015 to July 2016. Science Direct, Economic Papers (Econpapers), Economic Literature (Econlit), Research Papers in Economics (RePEc), Google Scholar and the mainstream Google search engine are examined for the relevant references. Irrespective of methodological underpinning and geographical focus, the base criteria for the selection of articles are recent information technology advances in finance for inclusive development.

The content analytical approach for the relevant references consists of first, situating issues of exclusive growth in the context of the literature before reviewing recent financial inclusion advances. Retained financial innovations are structured along three themes, notably: the rural/urban divide, women empowerment and human capital in terms of skills \& training. The financial instruments are articulated with case studies, innovations and investment strategies with particular emphasis, inter alia on: informal finance, microfinance, mobile banking, crowdfunding, microinsurance, Islamic finance, remittances, PES and the DIA initiative. 
In choosing the relevant references, studies published in the past seven years are given priority in order to accommodate the contemporary emphasis of technological advances articulated by the inquiry. Some studies are not considered simply because their English versions are unavailable. In accordance with the 'conceptual independence' approach to systematic reviews we neither reject inquires investigated in different countries with the same methodology nor investigations devoted to a particular set of nations with different methodological underpinnings. However, we avoid the trap of repetition by using multiple references to substantiate homogenous and harmonious perspectives. This is the case when qualitative and quantitative views on a specific advancement in information technology for inclusive development are recurrent as the literature review unfolds.

It is important to note that there is no clear consensus in the literature on how studies for a literature review should be undertaken. Whereas some authors in surveys have had a preference for one main observation per study (see Stanley, 2001), others have included all information that is available (see Florax et al., 2003). The analytical approach of this inquiry combines the two methods because we focus on direct and quantitative contributions of selected papers to the literature, as well as on indirect contributions or qualitative narratives on advances in information technology. Within the framework of the study, a direct contribution is an inquiry that entails an empirical assessment upon which there is an apparent causal relationship flowing from a technological advancement in finance to inclusive development. In the same vein, an indirect contribution to knowledge refers to a research that establishes a relationship between technological advancement in finance and inclusive development without an empirical analysis clarifying a casual relationship.

Four main steps are adopted in this review. Firstly, a pilot study is performed from which we gain insights into the major concerns about inclusive development. These include anxieties associated with the rural-urban divide, women empowerment, skills and training. Secondly, another pilot study enables us to have insights into recent technological innovations for inclusive development, namely: informal finance, microfinance, mobile banking, crowdfunding, microinsurance, Islamic finance, remittances, PES and the DIA initiative. These perceptions are supported by evidence extracted by using the following search engines, inter alia: 'information technology for inclusive development'; 'information technology for non-exclusive development'; 'information technology for inclusive growth'; 'information technology for quality of growth'; 'information technology for quality of development'. Thirdly, the literature review is structured according to identified themes of inclusive 
development and recent information technology advances in finance. At this stage, a detailed study of the literature is carried-out and the relevant references are categorised in the main strands identified in the second step. After this phase, the study is close to 30000 words. Fourthly, we contrast and compare literature within and across strands in order to avoid repetition, enhance clarity and improve the flow of surveyed knowledge. The outcome of the fourth step is a synthesised narrative of less than $50 \%$ of the initial 'word count'.

In the light of the above, this study is not a meta-analysis (because no empirical analysis is involved) but a content analysis. The steps elucidated have a logical flow. No coding was used to generate themes and no quantitative datasets were used to identify themes. Moreover, the themes based on the papers we identified were broadly consistent with themes within the selected papers.

\section{Financial Development and the Urban-Rural Divide}

This section attempts to look at the challenges of managing rural/urban migration and sustainability of rural economies, with particular emphasis on: employment, production and distribution of food, support of cooperatives and small and medium sized enterprises (SMEs) and demand- and supply-side constraints in agricultural productivity.

Recent evidence suggests that traditional financial development would aggravate rural-urban inequality in the long-term in India (Tiwari et al., 2013, p. 151). This narrative is consistent with China because credit is available exclusively to the rich (Xuelong, 2012, p. 696). Hence, wider credit coverage is vital to reducing inequality. Aggregate poverty reduction substantially depends on rural-urban inequality in a broader sample of South Asian countries (Sehrawat \& Giri, 2016). While the effect of financial deepening may not be clearcut in Africa (Baliamoune \& Lutz, 2005, p.1), in light of the conclusions of Xuelong, the relative concentration of financial institutions in urban areas of the African continent justifies a corresponding rural-urban income-inequality owing to less credit access in rural areas.

In light of heterogeneity in the benefits of financial development between developed and developing countries discussed above (Xuelong, 2012, p. 696), we critically evaluate both sets of countries. Section 3.1 discusses mobile/internet banking and rural development. Section 3.2 covers issues of coordinating rural-urban development and documents on how the financial system can be improved to mitigate corresponding concerns. Section 3.3 provides financial keys to tackling the rural-urban divide in developed countries. 


\subsection{Mobile and internet banking for rural development}

Motivated by prior exposition on the need for more research to establish the link between mobile phones and development (Mpogole et al., 2008, p.71), Kliner et al. (2013) have shown that mobile phones improve health services for poor communities ${ }^{9}$. Kirui et al. (2013, p. 141) have also established the positive role of mobile banking in poverty mitigation in rural areas: 'We conclude that mobile phone-based money transfer services in rural areas help to resolve a market failure that farmers face; access to financial services' (p. 141). Warren (2007) has noted that the underprivileged, especially those in rural communities stand to reap the highest benefits from technology. In some fast growing developing countries, in spite of efforts from mainstream financial establishments, 'Telecommunication infrastructure growth especially mobile phone penetration has created an opportunity for providing financial inclusion' (Mishra \& Bisht, 2013, p.503). Singh (2012, p. 466) within the same framework of India is more direct in crediting 'mobile banking' for positive trends in financial inclusion. Baro and Endouware (2013) have shown that mobile phone related services contribute to socio-economic development in the rural areas of developing countries.

Consistent with the recent literature (Asongu, 2013a; Demombynes \& Thegeya, 2012), the revolution of the mobile phone has substantially transformed the lives of many in developing countries by enabling basic access to phone-based finance in addition to communication facilities. According to the narrative, the substantial growth in mobile telephony has transformed cell phones into pocket-banks. Such has provided economic opportunities for a substantial part of the population which, due to low-income status and rural geographic location, has been previously excluded from financial services. As noted by Warren, rural citizens should benefit most from internet services because its availability would substantially lessen distance barriers in aspects like information acquisition and purchase of commodities. We discuss the impact of mobile/internet banking in alleviating the implications of rural-urban divide in three main strands: (i) employment, production and distribution of food; (ii) support for cooperative and small and medium sized enterprises (SMEs) and (iv) demand- and supply-side constraints in agricultural productivity.

Firstly, employment, production and food distribution are some of the dire challenges confronting rural communities in many developing countries. Many youth are migrating to urban areas in search for work because of substantial production and distribution constraints

\footnotetext{
${ }^{9}$ The focus of the paper is on recent technologies. Hence, older technologies which are pro-poor are not considered. Hence it is not only mobile technologies that are addressing inclusive development.
} 
in the traditional agricultural sector. Hence, it is important to rethink new ways in which jobs could be created by producing and distributing food locally. Financial advances could help in storage, marketing and transportation. The absence of information on the highlighted issues represents a significant cost for rural farmers. Studies in Ghana have shown that access to market information by means of mobile telephony/banking could increase revenue by as much as 10 percent (E-agriculture, 2012, p. 6-9). Other examples include current applications in: India (Digital Green, e-Arik, e-Choupal, Honey Bee Network, ICAAP, IKSL, Intelligent, LifeLines India \& mKisan), Kenya (iCow, KUZA Doctor \& Ukulima.net), Egypt (VERCON \& RADCON), Uganda (AgriNet Uganda Ltd), the Middle East (CropLife,) and Africa (CropLife, ESOKO \& Satadsl).

Secondly, support for cooperatives and small and medium sized enterprises (SMEs) centres around how mobile banking applications stimulate agricultural finance. There is growing evidence of village banking institutions in Costa Rica using such a medium to create solidarity groups that are financially-sustainable (Perez et al., 2011, p. 316). Community Credit Enterprises (CCE) also enables members to generate capital and buy shares to ensure sustainable business and credit models. As far as we know, Chan \& Jia (2011) have provided one of the most interesting accounts of the role of mobile banking in easing rural finance and mitigating inequality in financial services between rural and urban areas. According to the narrative, 'mobile banking is an ideal choice for meeting the rural financial needs' (p. 3) and has led to substantial improvements in agricultural-related loans (see Figure 1, p. 3) due to increasing 'rates for bank transfers through mobile cell phones at commercial banks' (Table 2, p. 5). The corresponding table and figure are apparent in Chan \& Jia (2011). This is consistent with the World Bank's conclusions on mobile banking applications for rural and agricultural development (Qiang et al., 2011, pp. 14-26).

Thirdly, the examples provided in the first and second strands principally target the mitigation of demand- and supply-side constraints. These entail specific measures that promote agricultural productivity and growth such as mobile banking applications. In a nutshell, the fundamental question raised in this strand is whether mobile banking policies facilitate channels to markets which yield relatively higher returns to farmers in rural areas. In other words, the concern is how the rural population can escape the vicious cycle of reducing returns on agricultural capital and income growth. In summary, mobile phone/banking has enabled a better matching of demand and supply, especially among geographical markets. This matching exercise ultimately eliminates wastes (Muto \& Yamano, 2009, p.1887; Aker \& 
Fafchamps, 2010). In spite of above observations, Maurer (2008) has cautioned that policy has a very substantial role to play in rendering mobile banking services more inclusive.

\subsection{Coordination of rural-urban development}

Information technology can be harnessed to address poverty issues in urban areas (Omole, 2013) as well as community development concerns in rural areas (Breytenbach et al., 2013). While a lack of proper rural-urban development coordination in certain developing countries results from many factors, it is fundamentally driven by irrational financial policies (Li et al., 2011, p. 109). Coordinating rural-urban development is important because, among others, it elevates the living standard and quality of farmers while at the same time develops human resources; promotes healthy agricultural development and enhances rural-urban integration. Some issues in coordination (of balanced rural-urban progress and industrial structure) include: longstanding concerns of rural/urban gaps (of consumption, expenditure and income), unstable agricultural culture and worries about statistical data and social development. Some factors restricting rural-urban migration coordination include: insufficient input in rural education, low agricultural capital, and scanty investment in rural fixed assets. As far as we have reviewed, two financial development policy suggestions advanced to address the highlighted issues entail the promotion of financial policies innovation and financial system innovation.

In the first strand, there are at least three main reasons motivating the promotion of financial policy innovation for better rural/urban coordination. Firstly, a financial system should encourage and support funds for elementary schools by: providing guarantees for rural elementary education and providing more incentives for teachers to take positions in rural areas, amongst others. Secondly, consolidation of agricultural infrastructure with more financial inputs involves, inter alia, sound management of financial resources for povertyalleviation and amelioration of a price-subsidy channel for agricultural commodities. Thirdly, the establishment of a financial system that is sympathetic to bridging the rural/urban divide requires innovation in supply models and improvement of management/supervisory practices.

For the second strand, it is important to promote the innovation of a financial system for proper coordination of rural/urban development because of lack of financial access to rural and agricultural communities. Most farmers are left to rely on unlicensed financial institutions offering credit facilities at exorbitant interest rates (Li et al., 2011, p.114). Hence, it is essential to consider farmer-specific features in the allocation of financial products. The 
following are some policy measures. Firstly, there is the need to reinvent rural financial institutions and adapt educational training to the corresponding innovations so that consistent services are delivered to the rural communities. Secondly, it is important to encourage new financial products which entail, among others: spreading of agricultural credit risks, encouraging the credit models that enhance industrialised management of agriculture and floating of joint bond SMEs focused on agriculture. Thirdly, improvement in financial system patterns, like rural networked insurance, mobile banking and construction of village trust.

Fourthly, enhancing channels via which agricultural credits are subsidised like special poor-farmer loans and rural low interest policy funds, among others.

One of the most interesting accounts on recent financial development for 'leveraging the rural-urban nexus for development' has been provided by the International Fund for Agricultural Development (IFAD, 2014a) in its first post-2015 policy brief. The report which begins by clearly pronouncing that "The world cannot afford a future where rural areas are synonymous with social and economic marginalization" (p.1), has documented three major advances in finance by which the objectives outlined in this section can be achieved. These include: 'Key findings from an IFAD-World Bank study of international remittance flows to Asia' (p. 4), 'IFAD and payment for environmental services in Asia and Africa' (p. 6) and 'The Diaspora Investment in Agriculture (DIA) initiative' (p.8).

On the first point, some crucial findings by the IFAD-World Bank study have revealed that a significant chunk of remittances sent to developing countries is destined to rural areas. Hence, remittances are playing a comparatively larger role in financial inclusion relative to microfinance institutions. But the report cautions that for the inclusive benefits of such remittances to be fully exploited, remittance-receiving households should be provided with more options on how to use their money in order to substantially leverage the inclusive development effects of such financial inflows in their communities (e.g. see Efobi et al. [2015] for the Nigerian experience). According to the recommendation, effective financial inclusion would require a substantial commitment to programmes of financial literacy support for recipient households. One of such externalities is the positive trend of food security by means of Diaspora remittances.

The second argument on PES, which includes restoration of watersheds and maintenance, constitutes a novel source of providing financing support for the management of assets by rural communities. The mechanism also provides some advantages to other communities and water users downstream. Recent advances of PES are evident in Africa 
(Guinea, Uganda, Kenya \& Tanzania) and Asia (Indonesia, China, Vietnam, Philippines, Nepal \& the Lao People Democratic Republic). The programmes are realised by the IFAD in conjunction with the World Agroforestry Center (ICRAF) for both continents, with the collaboration of the 'Pro-poor Rewards for Environmental Services in Africa' (PRESA) and the 'Reward the Upland Poor of Asia for the Environment Services' (RUPES).

The third idea concerns the DIA initiative. According to the narrative, remittances from the Diaspora destined for agriculture represents about four times the amount of official development assistance (ODA) intended for the same purpose. The DIA has been launched by the IFAD and the USA in recognition of the increasing diaspora role. This partnership intends to encourage diaspora engagement in sustained and inclusive domestic economic growth via agricultural investment. Leveraging this contribution by migrant workers has positive externalities like: creation of local jobs, discouragement of outward migration intentions and poverty reduction. The DIA inclusive objectives of coordinating rural/urban development are achievable along three main channels. They comprise (i) encouraging the global diaspora to invest in sustainable agricultural projects with real potential to impact the lives of poor rural people', (ii) enabling diaspora investors, diaspora organizations and actors on the ground to build the capacity necessary to undertake cross-border investments and gain access to markets for traditional products and (iii) stimulating agricultural production and reducing import dependency to enhance food security' (IFAD, 2014a,p.8).

\section{Financial Development and Women Empowerment}

From a global perspective, in spite of a declining trend, women still generally have lower incomes than men (Weichselbaumer \& Winter-Ebmer, 2005, p. 479). According to Demirguc-Kunt \& Klapper (2013), access to formal financial institutions is 55 percent versus 47 percent for men and women, respectively. While the issue of 'gender gap in financial access' is less apparent in developed countries (van Hulten, 2012, p. 266), women in developing countries face substantial constraints with unequal access to finance (GPFI, 2011, p. 34-46). Having documented evidence of differences between men and women in access to finance, it is interesting to engage how existing disparities can be mitigated. In what follows, we discuss the relevance of mobile/internet banking in developing countries and incentives that are instrumental for decreasing the gender gap. 


\subsection{Mobile and internet banking and women empowerment}

There is growing evidence that mobile banking is increasing the social participation of women in marginalised societies. Corresponding channels of financial inclusion include, among others, strengthening of small businesses and household management. Consistent with Jonathan \& Camilo (2008), Asongu (2015a) and Ondiege (2010, 2013), mobile banking has enabled women to have more access to finance, hence easing the mitigation of a genderfinance gap. The narrative maintains that mobile banking is providing previously unbanked women with more affordable mechanisms to financial access.

Accordingly, mobile banking could considerably help women in household budget management, especially when households are faced with unpredictable poverty-oriented negative externalities. In line with Al Surikhi (2012), Asongu (2016) and Kemal (2018), advantages include, among others: timely responses, more experience in coping with negative shocks and better financial management. In more elaborate terms, the authors argue that mobile banking enables women to accomplish the following outcomes.

Firstly, it reduces the probability of women incurring great losses because money can be easily transferred in order to timely respond to unforeseen negative shocks. Hence, potential costs associated with such negative externalities are mitigated. Some avenues of shock mitigation and better financial management require lower travelling costs, less trauma and more efficient responses. As an example, in situations where women are particularly vulnerable to concerns like death, illness, cost reduction and the saving of income, mobile banking could be very useful.

Another advantage of mobile and internet banking is 'security amelioration' for women through cost-reduction. For instance, evidence about their timely ability to reduce overnight hospital days through the quick dial of a phone to send and receive money is well documented. This quick 'access to finance' is crucially important in periods of desperation. Hence, mobile banking provides opportunities for (i) reducing unexpected occurrences, (ii) multi-tasking and (iii) time required to solve crises. In summary, some essential areas of gender equality are fostered with more positive signals in economic empowerment, health, safety, education and social inclusion.

We invite the interested reader to refer to Mishra \& Bisht (2013, p. 505) and Ondiege (2010, p. 11) for country-specific models of financial inclusion linked to mobile banking. What is important to note for their effectiveness in empowering women is that, appropriate governance mechanisms are needed. For example, Ojo et al. (2012) have analyzed the 
livelihoods of women with access to mobile phones in Ghana to confirm this position (p. S30).

\subsection{Other financial related incentives and policies for gender empowerment}

Incentives that could bridge the gender gap with the help of mobile banking may involve business-to-business interactions among women. These policy interventions may include (i) mobile-health initiatives for children, (ii) fiscal incentives of specific nature, (iii) educational initiatives, (iv) targeted government rural/agricultural initiatives and (v) more broad use of mobile payments to females for earnings as nurses or family health visitors. There is considerable evidence of documented case studies supporting the effectiveness of mobile money in driving such financial inclusion. Some examples include 'how mobile money can drive financial inclusion for women at the bottom of the pyramid (BOP) in Indian Urban Centers' (Chavan et al., 2009, p. 475) and a review of 'mobile phone, livelihoods and the poor in Sub-Saharan Africa' (Porter, 2012, p. 241).

The IFAD (2014b) second policy brief on post-2015 rural development has particularly focused on promoting rural women empowerment ${ }^{10}$. Projects to which finance can be channelled to empower women include self-help groups that have boosted the power of women in South Asia (p. 5) and farmers' organisation in sub-Saharan Africa targeting sustainable agriculture (p. 7). More post-2015 insights can be found in IFAD (2015c) on sustainably boosting agricultural productivity and consolidating agricultural markets and, in IFAD (2014d), on strengthening risk management capacity and the resilience of rural households and smallholder farmers.

More targeted cases/studies through which gender financial inclusion can be enhanced include: 'measuring gender performance in micro finance' (Iskenderian, 2013); 'adjustment of framework conditions by regulators and policy makers' (Frickeinstein, 2013); 'going beyond expectations to gender analysis' (Ghosh \& Berfond, 2013) and 'banking on including women' (Koning, 2013).

'Valuing women's knowledge and experience creates opportunities for the whole community' (IFAD, 2014e, p. 7). Hence, it is important to stimulate the demand-side for the success of policies towards increasing female 'access to finance'. IFAD has documented the following conclusions from 'case studies' for mobilizing a 'gender advantage'. These are:

\footnotetext{
${ }^{10}$ The interested reader can find more information on 'IFAD policy briefs on rural development in the post-2015 agenda' on the following link: http://www.un-ngls.org/spip.php?article4502
} 
'Promoting equitable access to adaptation knowledge for women and men is a key practical step for inclusive adaptation'; 'Building on women's knowledge and experience creates opportunities for the whole community'; 'Investing in women brings economic returns for smallholder farmers'; 'It is important to tackle women's workloads, which are often greater than that of men's and tend to increase as a result of climate change'; 'Supporting women's equal voice in decision-making about adaptation strategies is needed in the home, in the community and at the national and global levels' (p. 6). In light of Ojo et al. (2012), the above can be achieved through more gender-specific policies targeting the use of mobile banking.

Other interesting case studies that have been documented by IFAD (2014e) are: 'Nigeria: Dedicated support for women and young people' (p.11); 'Mali: Unlocking the capacities of different generations' (p. 8); 'Mauritania: Men and women working together' (p. 10); 'Kyrgyzstan: Alternative income sources' (p.12); 'Peru: Reduced workloads and transformed gender roles' (p. 18); 'Bolivia: Building on indigenous women's knowledge' (p. 7); 'Bangladesh: Early warning systems' (p.9); 'Swaziland: Women, unity and water' (p.13);

'China: Access to clean energy' (p. 17) and 'India: Women's self-help groups heard at climate policy forum' (p.15).

We now briefly describe some of the important actions and policies so far implemented in three main strands: (1) establishment of a supportive environment to enable female entrepreneurs to have access to financial services; (2) encouragement of efforts which identify, support and evaluate replication of referenced models aimed at consolidating financial services to female entrepreneurs and (3) tailoring of efforts towards gathering SME finance gender-disaggregated data (GPFI, 2011, p. 48-61).

The first strand on a supportive environment for female entrepreneurs involves: (i) developing diagnostics and strategies of country-specific nature to integrate gender perspectives into the agenda of financial development; (ii) establishing a supportive regulatory and legal environmental framework; (iii) strengthening of the legal access of women to property because it augments asset control, ensures more oversight on collateral, strengthens their ability and incentivizes them to develop businesses ${ }^{11}$; (iv) encouraging formalization; (v) expanding financial infrastructure like collateral registries and credit

\footnotetext{
${ }^{11}$ The interested reader can find specific steps needed to address gender differences in economic rights on pages 58-59 (IFAD, 2014).
} 
bureaus that mitigate borrowing cost and augment access to finance; (vi) consolidating SMEs access to alternative dispute resolution channels and minor court claims; (vii) enhancing the capacity building of financial institutions to improve service to female entrepreneurs; (viii) expanding research into better ways of combining business training with financial access; (ix) designing effective channels for government support; $(\mathrm{x})$ appointing national reference models to champion/lead female SMEs ; (xi) constructing public-private dialogues that are inclusive by supporting women networks and (xii) providing specific goals and incentives for more procurement by the State of commodities for female-managed corporations.

In the second element, we are concerned with efforts towards identifying, evaluating and supporting the replication of successful models previously used to consolidate financial access to female entrepreneurs (p. 61). According to the narrative, recent advances have shown that actively focusing on female entrepreneurs could be very rewarding for commercial banks. In addition, there is an increasing need for more data on female-owned SMEs. Efforts that have been devoted towards capturing and replicating these models are fundamental to enabling female-owned enterprises to get access to the finance that they require to expand their businesses. Moreover, providing incentives for commercial financial institutions to segregate their clients (especially those managing SMEs) and to tailor additional financial services towards tackling very specific female needs are important policy initiatives.

The third strand focuses on female disaggregated 'SME finance data', in a coordinated manner. Major advances include: (i) building reliable and consistently disaggregated data on gender access to finance and businesses; (ii) the need for national financial authorities to distinguish among categories of financial services in their data collection process; (iii) facilitating online registration and computerization of businesses and (iv) including differentiated gender queries into the national survey on access to finance (p. 61-62).

\section{Financing Inclusive Human Capital: Skills and Training}

The role of information technology is critical in education, social and human development (Shraima \& Khlaifb, 2010; Gudmundsdottir, 2010; Nkansah \& Urwin, 2010; Negash, 2010; Brunello, 2010; Krauss, 2013). The knowledge economy (KE) has been documented to be vital for inclusive development (Lustig, 2011; Asian Development Bank, 2014). Accordingly, $\mathrm{KE}$ is pro-poor because it reduces inequality (Asongu, 2014b), especially through the instrument of mobile telephony (Asongu, 2015a). But given the broad concept of KE, we 
decided not to include all its four components, notably: (i) education, (ii) ICT, (iii) economic incentives and (iv) institutional regime and innovation. Hence, we limit our discussion in this section exclusively to education or human capital in terms of skills and training.

According to the Asian Development Bank (ADB, 2014, p. 68), inclusive education in terms of skills and training entail the following: (i) increasing avenues for skills and education in technology, sciences, mathematical and technology disciplines for the less advantaged; (ii) putting special focus on mitigating dropout and improving full-cycle senior secondary education completion to more equity in tertiary educational access; (iii) improving wage returns and prestige for technical qualification via associated degrees; (iv) adding to scarce world-class institutes of higher learning, supporting investments destined for mass acquisition of educational minimum quality standards; (v) creating business incubators and excellence centres in institutions of higher learning in smaller cities and towns and (vi) enhancing entrepreneurial education in college, vocational, technical and university institutions.

In light of the above, this section investigates financial instruments that are used to deliver public commodities with particular emphasis on, inter alia: educational delivery to young people, resource inequalities, mitigating academic drop-out rates, mass education with particular references to the socio-economically disadvantaged and more education for citizens in smaller cities and towns.

Firstly, there have been some significant financial advances towards providing more skills and education to the underprivileged, boosting mass acquisition of educational minimum standards with better focus on peripheral towns/cities. In accordance with recent literature, access to finance in a business environment has some influence on educational quality in African society, which ultimately engenders growth-enhancing rewards that have positive inclusive human development externalities. This description is in line with the assertion that greater financial access exposure enhances students' entrepreneurial acumen, sharpness and literacy in finance (Oseifuah, 2010; Gerba, 2012; Tchamyou, 2017). On a specific note, Tchamyou (2017) has argued that providing financial access for entrepreneurial education has the potential of decreasing the cost/time of starting a business. Mensah \& Benedict (2010) have shown the positive long-run effect of such entrepreneurial activity on poverty mitigation. This is consistent with the Gerba (2012) position that business studies motivate entrepreneurial intentions and Oseifuah (2010) on the connection between financial literacy and youth entrepreneurship. 
Interestingly, the narrative above is broadly consistent with: recent 'trends in the crowdfunding of educational technology start ups' (Antonenko et al., 2014, p. 36); the benefits of crowdfunding for inclusive partnerships in Europe (Hollow, 2013); the use of crowdfunding for 'the development and production of an information literacy' (Walsh, 2014, p. 63); the use of reciprocal-crowdfunding in Rwanda to enhance the entrepreneurial skills of disadvantaged students (Elkuch et al., 2013).

African and Asian nations like India are particularly relevant in the use of such financial mechanisms for acquisition of skills because they represent the fastest and largest burgeoning youth populations among the world's poorest nations. Such intensifies the urgent need for 'job creation programmes and the requirement of ICT skills'. Mobile banking has been documented to be essential for the success of Massive Online Open Courses (MOOCs) (Trucano, 2013; Porter, 2014). This new platform for the delivery of skills and training is creating novel opportunities for adaptation in the changing market structures, evolution of the business environment and mitigation of poverty.

Secondly, mobile banking has helped in delivering public health education; hence extending access to previously limited public services and directly tackling concerns of widening inequality. Moreover, microcredit institutions are also being increasingly reformed to provide health education/service that ultimately addresses inequality. As a case in point, many microcredit establishments are more and more bundling credit with education, health and other initiatives (Smith, 2002, p. 707). In Honduras and Ecuador for instance, 'healthbank participation' (i) substantially raises future healthcare over 'credit-only participation' and (ii) lessens a quick transition to bottle-feeding from breast-feeding with income growth. For brevity and lack of space we cannot review the plethora of examples on mobile-related health services. The interested reader can find some of these recent mobile health educational innovations in Labrique et al. (2013).

We devote some space to the apparent challenges of an aging population. 'Aging societies mean new era of banking' (Moreno \& Chan, 2014). According to the authors, by 2025, forty-six nations would have less young people than old, implying financial institutions need to rethink how their businesses are driven. It was noted that an aging population will influence banking in three areas. Firstly, the distribution of wealth is increasingly skewed towards this faction of the population. Secondly, customer behaviour and preferences in products as well as in demands are bound to change. Thirdly, increasing life expectancy with a relative advantage of women implies that they would accumulate larger chunks of wealth 
among the old (especially in nations like China and India). Financial institutions are currently integrating such shifts in social, demographic and economic into their business models, hence reinventing the banking world ${ }^{12}$.

\section{Informality, Microfinance, Crowdfunding, Microinsurance and Islamic finance}

\subsection{Informal finance, microfinance, crowdfunding and microinsurance}

There is a recent stream of literature on the interconnections among globalisation, informalisation and inclusiveness that should be organised in two parts. On the one hand, globalisation has boosted financial informalisation as opposed to formalisation (Asongu, 2015c). On the other, KE which we have covered in the preceding section, as having an appealing impact on inclusiveness has also been documented to be more positively linked with the informal financial sector as opposed the formal economic sector (Asongu, 2014c, 2015b).

In light of the above, informality is playing a substantial role in reducing inequality in less developed countries (Asongu, 2013, p. 301). The author assessed how globalisationdriven reforms have affected inequality via various channels (informal, non-formal and formal). It is also important to note that, mobile telephony is positively (negatively) correlated with the informal (formal) financial sector (Asongu, 2013a). In view of Asongu (2013c) , this is an indication that mobile phone usage is pro-poor.

The imperative to lay more emphasis on the role of the informal financial sector draws from the International Financial Statistics (IFS, 2008) definition of the financial system which does not take the informal financial sector into account ${ }^{13}$. The plethora of examples on the instrumentality of the informal financial sector in poverty reduction has been discussed above and will be further explained below. Our motivation for highlighting the informal financial sector is because, in spite of liberalisation policies boosting the informal sector to the detriment of the formal sector (Adeusi et al., 2012), very few studies have focused on the externalities of the corresponding evolving trend on informality (Fugazza \& Fiess, 2010; Bairagya, 2010; Asongu \& Nwachukwu, 2016a).

As far as we know, other improvements in microfinance that merit emphasis can be discussed along three main lines. Firstly, a strand on 'innovation in microfinance' which

\footnotetext{
12 The reader can find more information on: http://europe.chinadaily.com.cn/epaper/201412/19/content_19124583.htm

${ }^{13}$ The reader can refer to Lines 24,25 and 45 of the IFS (2008).
} 
highlights the need to focus beyond 'income poverty' or on 'social intermediation' rather than on financial intermediation. Accordingly, these document the need for exploring new frontiers of social and economic development, which entail, among other things, infrastructure for: skills, health, education and enterprise. Consistent with Hans (2009), this line of argument recommends a symbiotic relationship between social intermediation and financial intermediation in order to break socio-cultural and economic barriers to inclusive development and employment.

Secondly, it has been established that microfinance is a significant driver of the Gross National Happiness (GNH) index (Sharma, 2014, p.73). The author argues for the need to evaluate the effect of microfinance on happiness at an individual level.

Thirdly, owing to the relatively low rate of mainstream bank financing for SMEs (e.g Abor \& Biekpe ,2007, for Ghana), there has been substantial recourse to microfinance which is still not without controversy on interest rate dynamics. Kar and Swan (2014, p. 87) have argued that the interest rate charged by microfinance institutions (MFIs) has appealing effects on improving profitability, reducing repayments and leading to missing drift. The findings reveal that real yield positively impact on loan repayment rates and financial performance of MFIs. The link between performance and 'rates of interest' contrast with more recent evidence from Basharat et al (2015): "The results show that financial efficiency has a positive impact on interest rates, with more financially efficient MFIs having lower interest rates, while social efficiency has no impact on microcredit interest rates" (p. 49). Bumacov et al. (2014, p. 401) have concluded that microfinance institutions that employ credit scoring to enhance the effectiveness of their loan officers have enjoyed a substantial expansion in the number of loans and borrowers which ultimately expands financial inclusion and opportunities of development.

One important innovation in microfinance is Crowdfunding which is increasingly taking banks to the poor. A notable example is Kiva which has ambitions of facilitating financial access to the poor or to microfinance: 'Kiva's aim is to make microfinance, which is basically loans to some of the poorest people on the planet, easy' (Duncan, 2014). According to the World Bank (2013), the potential for this means of finance in developing countries is immense: 'Crowdfunding has emerged as a multi-billion dollar global industry' (p.7) because 'The rate of growth of crowdfunding, and its emergence in developing and developed countries, suggests that this phenomenon can become a tool in the innovation ecosystems of most countries' (p.8). 
There is also a growing body of literature on the inclusive development benefits from crowdfunding. According to Macht (2014, p. 439), entrepreneurs seeking funds who are also interested in enjoying benefits from their crowdfunders are very likely to positively influence their funders via trust-building and relationship marketing mechanisms. This finding is consistent with the conclusions of Assadi and Ashta (2014, p. 461) on the position that online groups associated with crowdfunding have been documented to be replicating group pressures that characterise offline microcredit groups. In summary, Royal and Windsor (2014, p. 425) have established that crowfunding is addressing gaps left by traditional financial institutions, especially in financing grass-root initiatives.

To the best of our knowledge, crowdfunding is being confronted with two main challenges (i) the need to take into account the identity it creates and disseminates via its communication (Attuel-Mendés et al., 2014, p. 493) and (ii) strategic setbacks due to the 'social lending market' demand- and supply-side barriers (Ashta et al., 2015, p. 1). Despite these ongoing challenges, the above studies clearly support the expanding role of crowdfunding in inclusive development.

The burgeoning microinsurance market in developing countries and incorporation of micro-products into existing strategies of insurance represent both developmental and commercial opportunities. Consequently, in the latter perspective, innovations in technology, new commodities and distribution mechanisms are contributing to the overcoming of barriers to regulatory uncertainty, meagre margins of profit and low customer awareness. On the developmental front, microinsurance is providing small businesses and households with growing certainty in future investments by lessening the effects of losses suffered by the most vulnerable in society. These advantages have been substantially discussed in the evolving microinsurance literature, most notably by McCord \& Osinde (2005) and Ito \& Kano (2010). Some documented services include: (i) health microinsurance with interesting examples in Uganda (Microcare, CIDR and the Kitovu Patient's Prepayment Scheme), Kenya (MediPlus and the Community Health Plan) and Tanzania (Poverty Africa and the Community Health Fund) by McCord \& Osinde (2005); (ii) rainfall insurance (Giné et al., 2010) and (iii) crop insurance enhancing farmers' access to more resources in the Sahel region (Koloma, 2015, p.115). 


\subsection{Recent trends in Islamic finance}

According to Forget (2009), the model of finance advanced by Islam is one of social responsibility that is more holistic relative to the version proposed by mainstream economic theories. Thus, “... The goals of socio-economic justice and equitable distribution of income and wealth are an integral part of the moral philosophy of Islam and are based on its unflinching commitment to human brotherhood" (Chapra, 1983, p.2). This account is consistent with Chapra (2008) more than two decades later. In accordance with the author, in order for a financial system to work towards advancing justice, in addition to the need for strength and stability, two more conditions need to be satisfied. First, it is necessary for financiers to take part in the sharing of risks and potential losses with entrepreneurs. Second, bank lending should not be exclusively devoted to the rich, but an equitable portion should also be tailored towards the poor in order to expand employment, mitigate poverty, improve economic opportunities and favour positive redistribution in wealth and income. As we have noted in the preceding sections, the two conditions clearly involve inclusive growth.

Recent trends reveal that the Islamic financial industry has advanced significantly in both geography and size (Nabi, 2013, p. 21). The author remarked that as of 2013, Islamic financial institutions were in the neighbourhood of 600 and working in about 75 jurisdictions. Such accords with the continuously positive evolutionary patterns revealed by Kuwait Finance House (KFH) (KFH Research, 2012). According to KFH Research (2012), Islamic finance has been on a continuous positive trend because of its inclusive appeal. In essence, from 150 billion USD in the mid-1990s, it was expected to reach 1.6 trillion by 2012 and projected to attain the 6.5 trillion mark by 2020. Nabi (2013, p. 22) further argues that the Islamic Financial Service Industry (IFSI) has grown at a Compound Annual Growth Rate (CAGR) of about 40.3 percent to an estimated 1.1 trillion USD in assets between 2004 and 2011. In the light of KFH Research (2012), some interesting tendencies that have contributed to the upward surge are noteworthy.

Firstly, the Sukuk ${ }^{14}$ segment (or issuance) has progressed at a 42.3 percent CAGR during the 2004-2011 period, to 85.1 billion USD from 7.2 billion USD. Interestingly, between January 1996 and September 2012, 396.4 billion USD of Sukuk was issued in global aggregate terms.

\footnotetext{
${ }^{14}$ Sukuk refers to an Arabic appellation of financial certificates, commonly known as the Islamic version of mainstream bonds.
} 
Secondly, while the Takaful ${ }^{15}$ segment may be small, its contribution has also been substantial: growing to an estimated 15.2 billion in 2012 and by a 23.1 percent CAGR during the period 2004 to 2011.

Thirdly, assets under some Islamic funds increased to 64 billion USD in October 2012 from 29 billion USD in 2004.

Fourthly, Islamic Microfinance is a very promising market niche: with 225 global providers of which 92 percent or 164 are in East Asia and Pacific and 72 providers in the Middle East and North Africa (MENA). Moreover, according to CGAP (2013), Shariacompliant usage was estimated to be at 1.28 million in 2012. To the best of our knowledge, some of the most interesting accounts documenting the promising trend of Islamic Microfinance for financial inclusion are provided by CGAP (2013) and Karim et al. (2008).

We briefly highlight the growing role of Islamic finance in the promotion of inclusive growth. Mohieldin et al. (2012) have concluded that it is one of the most promising mechanisms for lifting the poorest out of poverty. A good example is the Microfinance Development Program (MDP) which aims to boost the horizon of microfinance in order to better fight poverty. The programme which aims at increasing the outreach of the Islamic Microfinance industry is tailored by the Islamic Development Bank (IDB). It can be summarised in two ways: (1) a plethora of intervention modes designed to tackle a broad range of microfinance needs in the IDB member states in order to avoid the trap of one strategy-fits-all and (2) a leverage of partners and resources with well-grounded microfinance establishments such as the Department for International Development (DFID) and the Grameen Bank.

Some measures towards consolidating the inclusiveness of Islamic banking include, inter alia: (1) fortification of growth infrastructure of capital for SMEs and the creation of jobs for youth; (2) consolidation of financial inclusion via microfinance and merging it with parallel Islamic financial products (like Endowments, Micro-Takaful \& Zaqat); (3) boosting of private and public sector partnerships by means of Sukuk issuance for financing health, transport and education inclusiveness and (4) the building of dedicated corporate governance, risk management and sound regulatory frameworks for various factions of the Islamic Financial Service Industry to ensure sustainability (Nabi, 2013, p. 33). Recent examples of partnerships with the poor within the framework of an Islamic financial inclusive model

\footnotetext{
${ }^{15}$ This is a repayment and reimbursement co-operative system that accounts for the following, inter alia' compensation from an agreed fund destined to small contributions and repayment in events of losses (by people and corporations) from hazards.
} 
documented by Nabi (2013), include among others: local marketing and harvesting of rice in Indonesia; Livestock (goats and cows), rice and cotton growing in Pakistan; Olive orchards and oil mills in Palestine and the growing of greenhouse fruits and vegetables in the Sudan. It should be noted that, harvesting-and marketing- support for 'local market' and export purposes are also provided to most of the beneficiaries (e.g., in Pakistan and Sudan).

\section{Conclusion}

The policy debate has been shifting from the finance-growth nexus to the financeinequality relationship. In the transition from MDGs to SDGs, there has been an urgent policy challenge of putting some structure on recent information technology advances in finance for more inclusiveness. The overarching question tackled in this paper has been: to what degree has financial development contributed to providing opportunities of human development for those in the low-income strata and by what information technology mechanisms? We have systematically reviewed about 180 recently published papers to provide recent advances in finance for inclusive development. The contribution of the study in the light of extant literature has been discussed in the introduction. The analytical approach has consisted of first, situating issues of exclusive growth in the context of the literature and then reviewing recent financial inclusion growth strategies. Retained financial innovations have been structured along three themes: (i) the rural-urban divide, (ii) women empowerment and (iii) human capital in terms of skills and training. The financial policy initiatives have been supported with case studies, innovations and investment strategies with particular emphasis, inter alia on: informal finance, microfinance, mobile banking, crowdfunding, microinsurance, Islamic finance, remittances, PES and the DIA initiative.

On the useful application of this paper, our research should substantially benefit both scholars and practitioners in formulating and implementing policies that are friendly towards more inclusiveness. Financial instruments as well as best practices in some case studies can be translated to other countries with the same fundamental needs. The review is also relevant to corporations wishing to improve on their inclusiveness strategies. For example, there are reports underway (like the 'Vodafone SIM project') which are fundamentally motivated by ICT-development not featuring prominently in the current SDGs debates. Rising inequality has been a crucial item on the agenda of the Great 20 nations, less developed countries as well as emerging markets. All stakeholders can benefit from this study by adopting financial instruments that are consistent with their development needs and relevant to their 
environmental challenges. Some instruments of reference may not provide expected results when implemented in the same development environments. Understanding why such policies might fail is an interesting future research direction.

The main limitation of the study is the lack of a theoretical framing. As stated in the introduction, the purpose of the study is not to make a theoretical contribution to the literature. Hence, while reviewing the literature, a theoretical contribution was not in mind. The key contribution of this study to the literature has been to document recent advances in ways 'information technology-driven' financial progress could promote inclusive development. Future surveys should also articulate theoretical contributions. Moreover, focus on explicit innovation processes and socio-technical aspects should be considered in future studies.

\section{References}

1. Abiad, D., Detragiache, E., \& Tressel, T., (2008). “A New Database on Financial Reform”, IMF Working Paper No. 08/226, Washington.

2. Abor, J. Y., Amidu, Y., \& Issahaku, H., (2018). "Mobile Telephony, Financial Inclusion and Inclusive Growth", Journal of African Business, 18(4), pp. 430-453.

3. Abor, J., \& Biekpe, N., (2007). "Small Business Reliance on Bank Financing in Ghana", Emerging Market Finance and Trade, 43(4), pp. 93-102.

4. Adams, R. H., (2004). "Economic growth, inequality and poverty: Estimating the growth elasticity poverty", World Development, 32(12), pp. 1989-2014.

5. Adeusi, S. O., Azeez, B. A., \& Olanrewaju, H. A., (2012). "The Effect of Financial Liberalization on the Performance of Informal Capital Market", Research Journal of Finance and Accounting, 3(6), pp. 1-16.

6. Afutu-Kotey, R. L., Gough, K. W., \& Owusu, G., (2017). "Young Entrepreneurs in the Mobile Telephony Sector in Ghana: From Necessities to Aspirations", Journal of African Business, 18(4), pp. 476-491.

7. Aker, J. C., \& Fafchamps, M., (2010). "How Does Mobile Phone Coverage Affect FarmGate Prices? Evidence from West Africa", Department of Economics and the Fletcher School, Tufts University.

8. Al Surikhi, H. F., (2012). "Knowledge and Financial Management in Households: An Examination of Married Women's Perspectives in Chadbourn, North Carolina", Capstone Collection, Paper No. 2489, Brattleboro.

9. Ali, A. A., \& Thorbecke , E., (2000). "The State and Path of Poverty in Sub Saharan Africa: Some Preliminary Result", Journal of African Economies, 29(Suppl. 1), pp. 9-40. 
10. Anand, R., Mishra, S., \& Peiris, S. J., (2013). "Inclusive Growth: Measurement and Determinants", IMF Working Paper 13/135, Washington.

11. Antonenko, P. D., Lee, B. R., \& Kleinheksel, A. J., (2014). "Trends in the crowdfunding of educational technology start-ups, TechTrends, 58(6), pp. 36-41.

12. Anyanwu, J. C., (2014a). "Marital Status, Household Size and Poverty in Nigeria: Evidence from the 2009/2010 Survey Data", African Development Review, 26(1), pp. 118-137.

13. Anyanwu, J. C., (2014b). "Determining the correlates of poverty for inclusive growth in Africa", European Economics Letters, 3(1), pp. 12-17.

14. Anyanwu, J. C., (2013a). "Gender Equality in Employment in Africa: Empirical Analysis and Policy Implications”, African Development Review, 25(4), pp. 400-420.

15. Anyanwu, J. C., (2013b). "The correlates of poverty in Nigeria and policy implications", African Journal of Economic and Sustainable Development, 2(1), pp. 23-52.

16. Assadi, D., \& Ashta, A., (2014). "Innovative Transposition of Trust Mechanisms in Social Lending Groups from Offline to Online", Strategic Change, 23(7-8), pp. 461480 .

17. Ashta, A., Assadi, D., \& Marakkath, N., (2015). "The Strategic Challenges of a Social Innovation: The Case of Rang De in Crowdfunding", Strategic Change, 24(1), pp. 1-14.

18. Asian Development Bank (2014). "Innovative Asia: Advancing the Knowledge-Based Economy", The Next Policy Agenda, Asian Development Bank http://adb.org/sites/default/files/pub/2014/innovative-asia-knowledge-basedeconomy.pdf (Accessed: 07/02/2015).

19. Asongu, S. A., (2016). "Reinventing foreign aid for inclusive and sustainable development: Kuznets, Piketty and the great policy reversal", Journal of Economic Surveys, 30(4), pp. 736-755.

20. Asongu, S. A., (2015a). "The impact of mobile phone penetration on African inequality", International Journal of Social Economics, 42(8), 706-716.

21. Asongu, S. A., (2015b). "Financial Sector Competition and Knowledge Economy: Evidence from SSA and MENA Countries", Journal of the Knowledge Economy, 6(4), pp. 717-748.

22. Asongu, S. A., (2015c). "Liberalisation and financial sector competition: a critical contribution to the empirics with an African assessment", South African Journal of Economics, 83(3), pp. 425-451.

23. Asongu, S. A., (2014a). "Financial development dynamic thresholds of financial globalisation: evidence from Africa", Journal of Economics Studies, 41(2), pp. 166-195. 
24. Asongu, S. A., (2014b). "Software piracy, inequality and the poor: evidence from Africa", Journal of Economic Studies, 41(4), pp. 526-553.

25. Asongu, S. A., (2014c). "Knowledge Economy and Financial Sector Competition in African Countries", African Development Review, 26(2), pp. 333-246.

26. Asongu, S. A., (2013a). "How has Mobile Phone Penetration Stimulated Financial Development in Africa?", Journal of African Business, 14(1), pp. 7-18.

27. Asongu, S. A., (2013b). "How do financial reforms affect inequality through financial sector competition? Evidence from Africa”, Economics Bulletin, 33(1), pp. 401-414.

28. Asongu, S. A., (2013c). "How do institutions matter in the income-equalizing effect of mobile phone penetration?", European Economics Letters, 2(2), pp. 56-61.

29. Asongu, S. A., \& Boateng, A., (2018). "Introduction to Special Issue: Mobile Technologies and Inclusive Development in Africa", Journal of African Business, 19(3), pp. 297-301.

30. Asongu, S. A., \& le Roux, S., (2017). "Enhancing ICT for Inclusive Human Development in Sub-Saharan Africa". Technological Forecasting and Social Change. 118(May), pp. 44-54.

31. Asongu, S. A., \& Nwachukwu, J. C., (2016a). "Mobile Phone Penetration, Mobile Banking and Inclusive Development in Africa", African Finance Journal, 18(1), pp. 3452.

32. Asongu, S. A., \& Nwachukwu, J. C., (2016b). "The Role of Governance in Mobile Phones for Inclusive Human Development in Sub-Saharan Africa", Technovation, 55-56 (September-October), pp. 1-13.

33. Asongu, S. A. \& Nwachukwu, J. C., (2017) "Finance and Inclusive Human Development: Evidence from Africa", African Governance and Development Institute Working Paper, Yaoundé.

34. Asongu, S. A., \& Nwachukwu, J. C., (2018). "Comparative human development thresholds for absolute and relative pro-poor mobile banking in developing countries". Information Technology \& People, 31(1), pp. 63-83.

35. Asongu, S. A., Nwachukwu, J. C., \& Orim, S-M, I., (2018). "Mobile phones, institutional quality and entrepreneurship in Sub-Saharan Africa", Technological Forecasting and Social Change, 131(June), pp. 183-203.

36. Asongu, S. A., \& Odhiambo, M. N., (2018). "Doing Business and Inclusive Human Development in Sub-Saharan Africa", African Journal of Economics and Management Studies. DOI: 10.1108/AJEMS-05-2018-0132 
37. Assadi, D., \& Ashta, A., (2014). "Innovative Transposition of Trust Mechanisms in Social Lending Groups from Offline to Online", Strategic Change, 23(7-8), pp. 461-480.

38. Atkinson, A. B., Piketty, T., Saez, E., (2011). "Top Incomes in the Long Run of History", Journal of Economics Literature, 49(1), pp. 3-71.

39. Attuel-Mendés, L., \& Caseau, C., \& Bonescu, M., (2014). "Brand Identity Process of Financial Cooperatives: An Austrian Case”, Strategic Change, 23(7-8), pp. 493-506.

40. Azzimonti, M., De Francisco, E., \& Quadrini, V., (2014). "Financial Globalisation, Inequality and the Rising Public Debt", American Economic Review, 104(8), pp. $2267-$ 2302.

41. Bairagya, I., (2010). "Liberalization, Informal Sector and Formal-Informal Sectors' Relationship: A Study of India", Institute for Social and Economic Change, Nagarbhavi, Bangalore, India. http://www.iariw.org/papers/2010/3Indrajit.pdf (Accessed: 11/02/2015).

42. Baliamoune-Lutz, M., \& McGillivray, M., (2009). "Does Gender Inequality Reduce Growth in Sub-Saharan Africa and Arab Countries?", African Development Review, 21(2), pp. 224-242.

43. Baliamoune-Lutz, M., (2007). "Globalisation and Gender Inequality: Is Africa Different?”, Journal of African Economies, 16(2), pp. 301-348.

44. Baliamoune, M., \& Lutz, S., (2005). "Rural-urban inequality in Africa: A panel study of the effects of trade liberalization and financial deepening", Journal of African Development, 7(1), 1-19.

45. Batuo, M. E., Guidi, F., \& Mlambo, K., (2010, August). "Financial Development and Income Inequality: Evidence from African countries". African Development Bank, Tunis.

46. Batuo, M. E., \& Asongu, S. A., (2015). "The impact of liberalisation policies on income inequality in African countries", Journal of Economics Studies, 41(2), pp. 68-100.

47. Baro, E. E., \& Endouware, B. C., (2013). "The Effects of Mobile Phone on the Socioeconomic Life of the Rural Dwellers in the Niger Delta Region of Nigeria", Information Technology for Development, 19(3), pp. 249-263.

48. Bhagwati, J., (1998). "The Capital Myth. The Difference between Trade in Widgets and Dollars”, Foreign Affairs, 7(3), pp. 7-12.

49. Bhagwati, J., (1958). "Immiserizing growth: A geometrical note", Review of Economic Studies, 25(3), pp. 201-205.

50. Bongomin, G. O. C., Ntayi, J. M., Munene J. C., \& Malinga, C. A., (2018). "Mobile Money and Financial Inclusion in Sub-Saharan Africa: the Moderating Role of Social Networks", Journal of African Business, 18(4), pp. 361-384. 
51. Brada, J. C., \& Bah, E. M. (2014). "Growing Income Inequality as a Challenge to 21st Century Capitalism", Italian Association for the Study of Economic Asymmetries Working Paper No. 1402, Rome.

52. Breytenbach, J., De Villiers, C., \& Jordaan, M., (2013). "Communities in control of their own integrated technology development processes", Information Technology for Development, 19(2), pp. 133-150.

53. Brunello, P., (2010). "ICT for education projects: a look from behind the scenes", Information Technology for Development, 16(3), pp.232-239.

54. Bumacov, V., Ashta, A., \& Pritam, S., (2014). "The Use of Credit Scoring in Microfinance Institutions and Their Outreach", Strategic Change, 23(7-8), pp. 401-413.

55. Byrne, E., Nicholson, B., \& Salem, F., (2011). "Information communication technologies and the millennium development goals", Information Technology for Development, 17(1), pp. 1-3.

56. Carmody, P., (2013). "A knowledge economy or an information society in Africa? Thintegration and the mobile phone revolution", Information Technology for Development, 19(1), pp. 24-39.

57. CGAP (2013). "Trends in Sharia-Compliant Financial Inclusion", Focus Note No 84, March 2013.

58. Chan, A., \& Jia, T., (2011). "The Role of Mobile Banking in Facilitating Rural Finance: Reducing Inequality in Financial Services between Urban and Rural Areas", Accenture Banking Services, http://www.accenture.com/SiteCollectionDocuments/PDF/PoVMobile-Banking-051611-EN.pdf (Accessed: 02/02/2015).

59. Chapra, M. U. (1983). "Monetary Policy in an Islamic Economy" in Ziauddin Ahmed, et. al. eds., "Money and Banking in Islam", International Centre for Research in Islamic Economics, Jeddah, KSA, 1983.

60. Chapra, M. U. (2008). "Innovation and Authenticity in Islamic Finance", paper presented in the "Eighth Harvard University Forum on Islamic Finance: Innovation and Authenticity", April 19-20, 2008.

61. Chavan, A. L., Arora, S., Kumar, A., \& Koppula, P., (2009), "How Mobile Money Can Drive Financial Inclusion for Women at the Bottom of the Pyramid (BOP) in Indian Urban Centers", Internationalization, Design and Global Development, Lecture Notes in Computer Science, 5623 (2009), pp 475-484.

62. Chavula, H. K., (2013). "Telecommunications development and economic growth in Africa", Information Technology for Development, 19(1), pp. 5-23.

63. Covert, B., (2015). "The 1 Percent Have Gotten All The Income Gains From The Recovery", Think Progress, 
http://thinkprogress.org/economy/2015/01/28/3616308/income-inequality-2013/ (Accessed: 04/02/2015).

64. Datt, G., \& Ravallion, M., (1992). "Growth and Redistribution Component of Changes in Poverty Decomposition to Brazil and India in the 1980s", Journal of Development Economics, 38 (2), pp. 275-295.

65. Demirguc-Kunt, A., \& Klapper, L., (2013) “The Gender Gap in Access to Finance”, The World Bank, http://blogs.worldbank.org/psd/the-gender-gap-in-access-to-finance (Accessed: 03/02/2015).

66. Demombynes, G., \& Thegeya, A. (2012, March). "Kenya's Mobile Revolution and the Promise of Mobile Savings". World Bank Policy Research Working Paper, No. 5988, Washington.

67. Dollar, D., \& Kraay, A., (2003), "Institutions, Trade, and Growth," Journal of Monetary Economics, 50, (1), pp. 133-162.

68. Duncan, N., (2014). "Crowdfunding development: 'Kiva's aim is to make microfinance easy", theguardian, Impact and effectiveness View from the top, http://www.theguardian.com/global-development-professionalsnetwork/2014/jun/10/crowdfunding-for-development (Accessed: 05/02/2015).

69. E-agriculture (2012). "Using ICT to enable Agricultural Innovation Systems for Smallholders", e-source book, ICT In Agriculture, Connecting Small Holders to Knowledge, Networks and Institutions, (Forum 4, September 2012). http://www.fao.org/docrep/018/ar130e/ar130e.pdf (Accessed: 02/02/2015).

70. Easterly, W., (2000). The Effect of IMF and World Bank Programs in Poverty, Washington DC: World Bank, Mimeo.

71. Efobi, U., Osabuohien, S. E., \& Oluwatobi, S., (2015). “One Dollar, One Bank Account: Remittance and Bank Breadth in Nigeria", Journal of International Migration and Integration, 16(3), pp. 761-781.

72. Elkuch, A., Brunner, C., \& Marxt, C., (2013). "Reciprocal crowdfunding as means to enable student and graduate entrepreneurship in Africa - a case study of Rwanda", International Journal of Entrepreneurship and Small Business, 19(4), pp. 498-516.

73. Elu J., \& Loubert, L., (2013). "Earnings Inequality and the Intersectionality of Gender and Ethnicity In SubSaharan Africa: The Case of Tanzanian Manufacturing", American Economic Review, Papers and Proceedings 04/2013, 103(103), pp. 289-292.

74. Fischer, S., (1998). "Capital Account Liberalization and the Role of the IMF", in "Should the IMF Pursue Capital-Account Convertibility?", Essays in International Finance, Department of Economics, Princeton University, 207, pp. 1-10.

75. Florax, R. J. G. M., Travisi, C. M., Njikamp, P., (2003). "A meta-analysis of the willingness to pay for reductions in pesticide risk exposure", European Review of Agricultural Economics, 32(4), pp. 441-467. 
76. Forget, E., (2009). "Le développement durable dans la finance éthique et la finance islamique", Cahier de la finance islamique, No. 1 ( June 2009), pp. 1-4.

77. Fosu, A. K., (2015). "Growth, Inequality and Poverty in Sub-Saharan Africa: Recent Progress in a Global Context”, Oxford Development Studies, 43(1), pp. 44-59.

78. Fosu, A. K., (2008). "Inequality and the Growth-Poverty Nexus: Specification Empirics Using African Data”, Applied Economics Letters, 15(7), pp. 563-566.

79. Fosu, A. K., (2009). "Inequality and the Impact of Growth on Poverty: Comparative Evidence for Sub-Saharan Africa", Journal of Development Studies, 45(5), pp. 726-745.

80. Fosu, A. K., (2010a). "The Effect of Income Distribution on the Ability of Growth to Reduce Poverty: Evidence from Rural and Urban African Economies", American Journal of Economics and Sociology, 69(3), pp. 1034-1053.

81. Fosu, A. K., (2010b). "Does Inequality Constrain Poverty Reduction Programs? Evidence from Africa", Journal of Policy Modeling, 32(6), pp. 818-827.

82. Fosu, A. K., (2010c). "Inequality, Income and Poverty: Comparative Global Evidence", Social Sciences Quarterly, 91(5), pp. 1432-1446.

83. Freeman, R. B., (2010). “It's financialization”, International Labour Review, 149(2), pp. 163-183.

84. Frickeinstein, J., (2013, December). "Advancing Financial Inclusion for Women in Africa", CGAP, Advancing financial inclusion to improve the lives of the poor http://www.cgap.org/blog/advancing-financial-inclusion-women-africa (Accessed: 03/02/2015).

85. Fugazza, M., \& Fiess, N., (2010). "Trade liberalization and informality: new stylized facts", Policy Issues in International Trade and Commodities Study Series No. 43. http://unctad.org/en/docs/itcdtab44_en.pdf (Accessed: 11/02/2015).

86. Gerba, D. T. (2012). "Impact of entrepreneurship education on entrepreneurial intentions of business and engineering students in Ethiopia", African Journal of Economic and Management Studies, 3(2), pp. 258-277.

87. GPFI (2011). "Strengthening Access to Finance for Women-Owned SMEs in Developing Countries", Global Partnership for Financial Inclusion, http://www.ifc.org/wps/wcm/connect/a4774a004a3f66539f0f9f8969adcc27/G20_Wo men_Report.pdf?MOD=AJPERES (Accessed: 03/02/2015).

88. Ghosh,, S., \& Berfond, J., (2013, October). "Beyond Expectations: Application of Gender Analysis", CGAP, Advancing financial inclusion to improve the lives of the poor http://www.cgap.org/blog/beyond-expectations-applications-gender-analysis (Accessed: 03/02/2015). 
89. Giné, X., Menand, L., Townsend, R., \& Vickery, J., (2010). “Microinsurance: a case study of the Indian rainfall index insurance market", Policy Research Working Paper http://dx.doi.org/10.1596/1813-9450-5459.

90. Gosavi, A., (2018). "Can mobile money help firms mitigate the problem of access to finance in Eastern sub-Saharan Africa”, Journal of African Business. 18(4), pp. 343-360.

91. Gudmundsdottir, G. B., (2010). "When does ICT support education in South Africa? The importance of teachers' capabilities and the relevance of language", Information Technology for Development, 16(3), pp. 174-190.

92. Hans, V. B., (2009). "Innovations in Microfinance - Looking beyond Income Poverty", Department of Economics, St Aloysius Evening College, Mangalore, India. http://papers.ssrn.com/sol3/papers.cfm?abstract_id=1392623 (Accessed: 05/02/2015).

93. Henry, P. B., (2007). "Capital Account Liberalization: Theory, Evidence and Speculation”, Journal of Economic Literature, 45(4), pp. 887-935.

94. Hollow, M., (2013). "Crowdfunding and Civic Society in Europe: A Profitable Partnership?", Open Citizenship, 4(1), pp. 68-73.

95. Hubani, M., \& Wiese, M., (2018). “A Cashless Society for All: Determining Consumers' Readiness to Adopt Mobile Payment Services", Journal of African Business, 18(4), pp. 409-429.

96. IFAD, (2014a). "Leveraging the rural-urban nexus for development", IFAD POST-2015 POLICY BRIEF 1, http://www.ifad.org/pub/post2015/english/1.pdf (Accessed: $11 / 02 / 2015)$.

97. IFAD, (2014b). "An empowerment agenda for rural livelihoods", IFAD POST-2015 POLICY BRIEF 2, http://www.ifad.org/pub/post2015/english/2.pdf (Accessed: $11 / 02 / 2015)$.

98. IFAD, (2014c). "Investing in small holder family agriculture for global food security and nutrition”, IFAD POST-2015 POLICY BRIEF 3, http://www.ifad.org/pub/post2015/english/3.pdf (Accessed: 11/02/2015).

99. IFAD, (2014d). "Promoting the resilience of poor rural households", IFAD POST-2015 POLICY BRIEF 4, http://www.ifad.org/pub/post2015/english/04.pdf (Accessed: $11 / 02 / 2015)$.

100. IFAD, (2014e). "The Gender Advantage: Women on the front line of climate change", International Fund for Agricultural Development. http://www.ifad.org/climate/resources/advantage/gender.pdf (Accessed: 03/02/2015).

101. Ifzal Ali, (2007), "Inequality and the Imperative for Inclusive Growth in Asia", Asian Development Review, 24(2), pp.1-16. 
102. IMF Statistics Department, (2008, October). "International Financial Statistics Yearbook, 2008", IMF, Washington.

103. Issahaku, H., Abu, B. M., \& Nkegbe, P. K., (2018). "Does the Use of Mobile Phones by Smallholder Maize Farmers Affect Productivity in Ghana?", Journal of African Business, 19(3), pp. 302-322.

104. Iskenderian, M. E., (2013, October). "Prove It: Measuring Gender Performance in Microfinance", CGAP, Advancing financial inclusion to improve the lives of the poor http://www.cgap.org/blog/prove-it-measuring-gender-performance-microfinance (Accessed: 03/02/2015).

105. Ito, S., \& Kano, H., (2010). "Why is the take-up of microinsurance so low? Evidence from a health insurance scheme in India", The Developing Economies, 48(1), pp. 74-101

106. Jonathan, D., \& Camilo, T., (2008). "Mobile banking and economic development: Linking adoption, impact and use", Asian Journal of Communication, 18(4), pp. 318322.

107. Kakwani, N., (1993). "Poverty and Economic Growth with Application to Côte d'Ivoire", Review of Income and Wealth, 39(2) pp. 121-139.

108. Kalwij, A., \& Verschoor, A., (2007). "Not by Growth Alone: The Role of the Distribution of Income in Regional Diversity in Poverty Reduction", European Economic Review, 51(4), pp. 805-829.

109. Kamel (2005). "The use of information technology to transform the banking sector in developing nations", Information Technology for Development, 11(4), pp. 305-312.

110. Kar, A. K., \& Swan, R. B., (2014). "Interest Rates and Financial Performance of Microfinance Institutions: Recent Global Evidence”, European Journal of Development Research, 26(1), pp. 87-106.

111. Karim, N., Tarazi, M., \& Reille, X., (2008). "Islamic Microfinance: An Emerging Market Niche", CGAP: Advancing financial Inclusion to improve the lives of the poor http://www.cgap.org/publications/islamic-microfinance-emerging-market-niche (Accessed: 05/02/2015).

112. Karippacheril, T. G., Nikayin, F., de Reuver, M., \& Bouwman, H., (2013). "Serving the poor: Multisided mobile service platforms, openness, competition, collaboration and the struggle for leadership", Telecommunications Policy, 37(1), pp. 24-34.

113. Kemal, A. A., (2018). "Mobile banking in the government-to-person payment sector for financial inclusion in Pakistan", Information Technology for Development. DOI: /10.1080/02681102.2017.1422105.

114. KFH Research (2012). "Global Islamic Assets \& Wealth Management 2013”, KFH Research Ltd, 23 November 2012. 
http://www.kfhresearch.com/product/global-islamic-assets-wealth-management-2013 (Accessed: 04/02/2015).

115. Kivunike, F. N., Ekenberg, L., Danielson, M., \& Tusubira. F.F., (2011). "Perceptions of the role of ICT on quality of life in rural communities in Uganda", Information Technology for Development, 21(1), pp. 61-80.

116. Kliner, M., Knight, A., Mamvura, C., Wright, J., \& Walley, J., (2013). "Using no-cost mobile phone reminders to improve attendance for HIV test results: a pilot study in rural Swaziland", Infectious Diseases of poverty, 2(12), pp. 1-7.

117. Koloma,Y., (2015). "Crop Microinsurance for Maize Farmers in Burkina Faso: Access and Agriculture Performance in the Dandé Village" ", Strategic Change, 24(1), pp. 115129.

118. Koning, A., (2013, December). "Banking on Including Women in Nigeria", CGAP, Advancing financial inclusion to improve the lives of the poor http://www.cgap.org/blog/series/how-make-financial-inclusion-work-women (Accessed: 03/02/2015).

119. Kose, M. A., Prasad, E. S., \& Taylor, A. D., (2011). "Threshold in the process of international financial integration", Journal of International Money and Finance 30(1), pp.147-179.

120. Kose, M. A., Prasad, E. S., and Rogoff, K., Wei, S. J., (2006). "Financial globalization: a reappraisal", IMF Staff Papers, 56(1), pp. 8-62.

121. Krauss, K., (2013). "Collisions between the Worldviews of International ICT PolicyMakers and a Deep Rural Community in South Africa: Assumptions, Interpretation, Implementation, and Reality", Information Technology for Development, 19(3), pp. 296318.

122. Kuznets, S. (1955). "Economic Growth and Income Inequality". American Economic Review , 45(1), pp. 1-28.

123. Kuznets, S., (1971). Economic Growth of Nations: Total Output and Production Structure. Belknap Press/Harvard University Press: Cambridge (Mass).

124. Labrique, A. B., Vasudevan, L., Kochi, E., Fabricant, R., \& Mehl, G., (2013). "mHealth innovations as health system strengthening tools: 12 common applications and a visual framework", Global Health Science and Practice, 1(2), pp. 160-171.

125. Laguerre, M. S., (2013). "Information technology and development: the Internet and the mobile phone in Haiti", Information Technology for Development, 19(2), pp. 100111. 
126. Levendis, J., \& Lee, S. H., (2013). "On the endogeneity of telecommunications and economic growth: evidence from Asia”, Information Technology for Development, 19(1), pp. 62-85.

127. Lewis, A., (1955). Theory of Economic Growth. Milton Park: Routledge.

128. Li, D., Guang-he, R., \& Jie, L., (2011). "The Problem of Coordinating Urban-rural Development in Chongqing City and Corresponding Measures of Financial Development", Asian Agricultural Research, 3(2), 109-115.

129. Liébana-Cabanillas, F., Sánchez-Fernández, J., \& Munoz-Leiva, F., (2014). “The moderating effect of experience in the adoption of mobilepayment tools in Virtual Social Networks: The m-Payment AcceptanceModel in Virtual Social Networks (MPAMVSN)", International Journal of Information Management, 34 (2014), pp. 151-166.

130. Lustig, N., (2011). "The Knowledge Bank and Poverty Reduction", Working Papers 209, ECINEQ, Society for the Study of Economic Inequality. Marglin, S. A. (2013).

131. Macht, S. A., (2014, p.439). "Reaping Value-Added Benefits from Crowdfunders: What Can We Learn from Relationship Marketing?", Strategic Change, 23(7-8), pp. 439-460.

132. Maurer, B., (2008, May). "Retail electronic payments systems for value transfers in the developing world", Department of Anthropology, University of California.

133. McCord, M. J., \& Osinde, S., (2005). "Reducing vulnerability: the supply of health microinsurance in East Africa", Journal of International Development, 17(3), pp. 327381.

134. Mensah, S. N., \& Benedict, E., (2010). "Entrepreneurship training and poverty alleviation: Empowering the poor in the Eastern Free State of South Africa", African Journal of Economic and Management Studies, 1(2), pp. 138-163.

135. Milanovic (2011) "More or Less ?" Finance \& Development, 48(3), September 2011. http://www.imf.org/external/pubs/ft/fandd/2011/09/Milanovic.htm

(Accessed: 04/02/2015).

136. Minkoua Nzie, J. R., Bidogeza, J. C., \& Ngum, N. A., (2018). "Mobile phone use, transaction costs, and price: Evidence from rural vegetable farmers in Cameroon", Journal of African Business, 19(3), pp. 323-342.

137. Mishra, V., \& Bisht, S. S., (2013). "Mobile banking in a developing economy: A customer-centric model for policy formulation", Telecommunications Policy, 37(6-7), pp. 503-514.

138. Mlachila, M., Tapsoba, R., \& Tapsoba, S. J. A., (2017). “A Quality of Growth Index for Developing Countries: A Proposal”, Social Indicators Research,. 134(2), pp 675710. 
139. Mohieldin, M., Z. Iqbal, A, Rostom, and X. Fu (2012) "The Role of Islamic Finance in Enhancing Financial Inclusion in Organization of Islamic Cooperation (OIC) Countries", Islamic Economic Studies, 20(2), pp. 55-119.

140. Moreno, J. P., \& Chan, A., (2014). "Aging societies mean new era of banking", ChinaDaily, http://europe.chinadaily.com.cn/epaper/2014-12/19/content_19124583.htm (Accessed: 11/02/2015).

141. Motelle, S., \& Biekpe, N., (2015). "Financial Integration And Stability In The Southern African Development Community”, Journal of Economics and Business, 79 (May-June), pp. 100-117.

142. Mpogole, H., Usanga, H., \& Tedre, M., (2008). "Mobile phones and poverty alleviation: a survey study in rural Tanzania", Proceedings of M4D 2008, Karlstad University, Sweden, pp. 62-72.

143. Muthinja, M. M., \& Chipeta, C., (2018). "What Drives Financial Innovations in Kenya's Commercial Banks? An Empirical Study on Firm and Macro-Level Drivers of Branchless Banking”, Journal of African Business, 18(4), pp. 385-408.

144. Muto, M., \& Yamano, T., (2009). "The Impact of Mobile Phone Coverage Expansion on Market Participation: Panel Data Evidence from Uganda", World Development, 37(12), pp. 1887-1896.

145. Nabi, M. S., (2013), "Role of Islamic Finance in Promoting Inclusive Economic Development", Global Sustainable Finance Conference 2013, Germany (4th to 5th July 2013), http://www.wfdfi.net/wp-content/uploads/2013/09/6-Mahmud_Nabi.pdf (Accessed: 04/02/2015).

146. Nasri, W., \& Charfeddine, L., (2012). "Factors affecting the adoption of Internet banking in Tunisia: An integration theory of acceptance model and theory of planned behaviour", Journal of High Technology Management Research, 23(1), pp. 1-14.

147. Negash, S., (2010). "Learning assessment of a videoconference-based training: lessons from medical training between USA and Ethiopia", Information Technology for Development, 16(3), pp.212-231.

148. Nkansah, G. B., \& Urwin, T., (2010). "The contribution of ICTs to the delivery of special educational needs in Ghana: practices and potential", Information Technology for Development, 16(3), pp. 191-210.

149. Obstfeld, M., \& Taylor, A. M., (2005). "Global Capital Markets Integration, Crisis and Growth", Cambridge University, New York.

150. Odhiambo, N. M., (2013). "Is financial development pro-poor or pro-rich? Empirical evidence from Tanzania”, Journal of Development Effectiveness, 5(4), pp. 489-500. 
151. Odhiambo, N. M., (2011). "Growth, Employment and Poverty in South Africa: In Search of a Trickle-Down Effect”, Journal of Income Distribution, 20(1), pp. 49-62.

152. Odhiambo, N. M., (2010a). "Financial deepening and poverty reduction in Zambia: an empirical investigation”, International Journal of Social Economics, 37(1), pp. 41-53.

153. Odhiambo, N. M., (2010a). "Is financial development a spur to poverty reduction? Kenya's experience", Journal of Economic Studies, 37(3), pp. 343-353.

154. Odhiambo, N. M., (2009). "Finance-growth-poverty nexus in South Africa: A dynamic causality linkage", Journal of Behavioral and Experimental Economics, 38(2), pp. 320-325.

155. OECD (2006). "Investment Priorities for Rural Development", The Hub, Edinburgh, Scotland, October 19-20, 2006. http://www.oecd.org/gov/regionalpolicy/Investment\%20priorities.pdf (Accessed: 31/01/2015).

156. Ojo, A., Janowski, T., \& Awotwi, J., (2012). "Enabling development through governance and mobile technology", Government Information Quarterly, 30 (Suppl. 1), pp. S32-S45.

157. Omole, D. W., (2013). "Harnessing information and communication technologies (ICTs) to address urban poverty: Emerging open policy lessons for the open knowledge economy”, Information Technology for Development, 19(1), pp. 86-96.

158. Ondiege, P., (2013). "Fostering financial inclusion with mobile banking", African Development Bank.

http://www.proparco.fr/webdav/site/proparco/shared/PORTAILS/Secteur_prive_develop pement/PDF/SPD16/SPD16_Peter_Ondiege_UK.pdf (Accessed: 03/02/2015).

159. Ondiege, P., (2010). "Mobile Banking in Africa: Taking the Bank to the People", Africa Economic Brief, 1(8), pp. 1-16.

160. Oseifuah, E. K., (2010). "Financial literacy and youth entrepreneurship in South Africa", African Journal of Economic and Management Studies, 1(2), pp. 164-182.

161. Oxfam (2015). "Richest 1\% will own more than all the rest by 2016", Oxfam International, http://www.oxfam.org/en/pressroom/pressreleases/2015-01-19/richest-1will-own-more-all-rest-2016 (Accessed: 04/02/2015).

162. Perez, F., Gonzalez, C. J., \& Aaronson, X., (2011). "Village banking development model: FINCA Costa Rica”, Journal of Business Research, 64 (2011), pp. 316-324.

163. Piketty, T., (2014). "Capital in the Twenty First Century”, Harvard University Press.

164. Pinkivskiy, M., \& Sala-i-Martin, X., (2014). "Africa is on time”, Journal of Economic Growth, 19(3), pp. 311-333. 
165. Porteous, D., (2007). “Just how transformational is m-banking?”, FinMark Trust, http://www.microfinancegateway.org/sites/default/files/mfg-en-paper-just-howtransformational-is-m-banking-feb-2007.pdf (Accessed: 31/01/2015).

166. Porter, D., (2014). "MOOC on M4D", Commonwealth of Learning, http://dspace.col.org/bitstream/123456789/519/1/M4DMOOC_Porter.pdf (Accessed: 08/02/2015).

167. Porter, G., (2012). "Mobile Phones, Livelihoods and the Poor in Sub-Saharan Africa: Review and Prospect", Geography Compass, 6(5), pp. 241-259.

168. Prasad, E. S., and Wei. S. J., (2007). “China's Approach to Capital Inflows: Patterns and Possible Explanations". In S. Edwards ed., Capital Controls and Capital Flows in Emerging Economies: Policies, Practices, and Consequences. Chicago: University of Chicago Press, pp. 421-480.

169. Qiang, C. Z., Kuek, S. C., Dymond, A., \& Esselaar, S., (2011). "Mobile Applications for Agricultural and Rural Development", ICT Sector Unit, World Bank http://siteresources.worldbank.org/INFORMATIONANDCOMMUNICATIONANDTEC HNOLOGIES/Resources/MobileApplications_for_ARD.pdf (Accessed: 02/02/2015).

170. Qureshi, S., (2013a). "What is the role of mobile phones in bringing about growth?", Information Technology for Development, 19(1), pp. 1-4.

171. Qureshi, S., (2013b). "Networks of change, shifting power from institutions to people: how are innovations in the use of information and communication technology transforming development?", Information Technology for Development, 19(2), pp. 9799.

172. Qureshi, S., (2013c). "Information and Communication Technologies in the Midst of Global Change: How do we Know When Development Takes Place?", Information Technology for Development, 19(3), pp. 189-192.

173. Ravallion, M., (1997). "Can High Inequality Developing Countries Escape Absolute Poverty”, Economics Letters, 56(1), pp. 51-57.

174. Ravallion, M., \& Chen, S., (2003). "Measuring Pro-Poor Growth," Economics Letters,78(1), pp. 93-99.

175. Rodrik, D., (1998). "Who Needs Capital-Account Convertibility?" Essays in International Finance, No. 207 (Princeton, New Jersey: Princeton University).

176. Rodrik, D., \& Subramanian, A., (2009) "Why did financial globalization disappoint?" IMF Staff Papers, 56(1), pp. 112-138.

177. Royal, C., \& Windsor, G. S. S., (2014). "Microfinance, Crowdfunding, and Sustainability: A Case Study of Telecenters in a South Asian Developing Country", Strategic Change, 23(7-8), pp. 425-438. 
178. Sehrawat, M., \& Giri, A. K., (2016). "Financial development, poverty and rural-urban income inequality: evidence from South Asian countries", Quality and Quantity, 50(2), pp. 577-590.

179. Sharma, P. P., (2014). "Microfinance: The Catalyst of GNH Index", Parikalpana KIIT Journal of Management, 10(2), pp. 73-86.

180. Shraima, K. \& Khlaif, Z., (2010). "An e-learning approach to secondary education in Palestine: opportunities and challenges", Information Technology for Development, 16(3), pp. 159-173.

181. Sinha, G., (2015). "You have free access to this content Innovations in Microfinance: Examining New Product Development Process in Indian MFIs", Strategic Change, 24(1), pp. 15-32.

182. Singh, A. B., (2012). "Mobile banking based money order for India Post: Feasible model and assessing demand potential", Procedia - Social and Behavioral Sciences, 37(2012), pp. 466-481.

183. Smith, S. C., (2002). "Village Banking and Maternal and Child Health: Evidence from Ecuador and Honduras", World Development, 30(4), pp. 707-723.

184. Stanley, T. D., (2001). "Wheat from chaff: meta-analysis as a quantitative literature review”, Journal of Economic Perspectives, 15(3), pp. 131-150.

185. Stiglitz, J., (2000). "Capital Market Liberalization, Economic Growth and Instability", World Development, 28(6), pp. 1075-1086.

186. Summers, L. H., (2000). "International Financial Crises: Causes, Prevention and Cures", American Economic Review, 90(2), pp. 1-16.

187. Swamy, V., (2010). "Financial Development and Inclusive Growth: Impact of Government Intervention in Prioritised Credit", Zagreb International Review of Economics \& Business, 13(2) pp. 55-72.

188. Tchamyou, V. S., (2017). "The role of Knowledge Economy in African Business", Journal of the Knowledge Economy, 8(4), pp. 1189-1228.

189. Thorbecke, E., (2013). "The Interrelationship Linking Growth, Inequality and Poverty in Sub-Saharan Africa”, Journal of African Economies, 33(Suppl_1), pp. 15-48.

190. Tiwari, A. K., Shahbaz, M., \& Islam, F., (2013) "Does financial development increase rural-urban income inequality?: Cointegration analysis in the case of Indian economy", International Journal of Social Economics, 40(2), pp.151-168.

191. Trucano, M., (2013). "MOOCs in Africa", Working for a World Free of Poverty, the World Bank, http://blogs.worldbank.org/edutech/moocs-in-africa (Accessed: 08/02/2015). 
192. United Nations (2013). “A New Global Partnership: Eradicate Poverty and Transform Economies Through Sustainable Development", The Report of the High-Level Panel of Eminent Persons on the Post-2015 Development Agenda. http://www.un.org/sg/management/pdf/HLP_P2015_Report.pdf (Accessed: 24/10/2014).

193. Van Hulten, A., (2012). "Women access to SME finance in Australia", International Journal of Gender and Entrepreneurship, 4(3), pp. 266-288.

194. Walsh, A., (2014). "SEEK!: creating and crowdfunding a game-based open educational resource to improve information literacy", Insights: the UKSG journal, 27(1), pp. 63-67.

195. Warren, M., (2007). "The digital vicious cycle: links between social disadvantage and digital exclusion in rural areas”. Telecommunications Policy, 31(6-7), pp. 374-388.

196. Weichselbaumer, D., \& Winter-Ebmer, R., (2005). "A Meta-Analysis of the International Gender Wage Gap”, Journal of Economic Surveys, 19(3), pp. 479-511.

197. World Bank (2013). "Crowdfunding Potential for the Developing World", infoDev, Finance and Private Sector Development Department. Washington, DC: World Bank.

198. World Hunger (2010). "the major barrier to people's welfare and development," Hunger Notes, http://worldhunger.org/harmfuleconomicsystems.htm (Accessed: 04/02/2015).

199. Xuelong, W., (2012). "Financial development and rural-urban inequality: Evidence from China", Economics Bulletin, 32(2), pp.1625-1639.

200. Young, A., (2012). "The African growth miracle", Journal of Political Economy, 120 (4), pp. 696-739.

201. Zhang, X., (2010). "Income disparity and digital divide: The Internet Consumption Model and cross-country empirical research", Telecommunications Policy, 37(6-7), pp. 515-529. 